Article

\title{
Financial Reforms and Determinants of FDI: Evidence from Landlocked Countries in Sub-Saharan Africa
}

\author{
Husam Rjoub *, Mehmet Aga, Ahmad Abu Alrub and Murad Bein \\ Department of Accounting and Finance, Cyprus International University, Nicosia 99040, North Cyprus; \\ Maga@ciu.edu.tr (M.A.); Aalrub@ciu.edu.tr (A.A.A.); Mbein@ciu.edu.tr (M.B.) \\ * Correspondence: hrjoub@ciu.edu.tr
}

Academic Editor: Helmi Hamdi

Received: 14 June 2016; Accepted: 5 December 2016; Published: 1 January 2017

\begin{abstract}
The recognition of Foreign Direct Investment (FDI) as a source of funding to foster economic development in both developed and developing countries has been in ascendancy. The prime purpose of this study is to empirically investigate the determinants of FDI for the "landlocked countries" in Sub-Saharan Africa over the period 1995-2013. By employing panel data analysis, the result of the study revealed that domestic investment, trade (openness), human capital, political constraint, natural resource endowment and the market size (with the GDP growth as proxy) as having positive impact on determining FDI flow into the sample countries with only the countries' tax policies seen otherwise. Our study not only contributes to existing literature on FDI determinants by investigating landlocked countries of Sub-Saharan Africa (SSA) for the first time but also includes natural resources that the landlocked countries are endowed with, tax policies and political constraints in such countries for the stipulated period.
\end{abstract}

Keywords: FDI; panel GLS; landlocked countries

JEL Classifications: F21; C23

\section{Introduction}

The economic performance of Sub-Saharan Africa (SSA) countries has been comparatively poor using the southeast and east Asian economies as proxies, in spite of unprecedented efforts to improve commodities and trade with their trading counterparts across the world (Fosu et al., 2004 [1]; Arrighi, 2002 [2]; Ayittey, 2005 [3]; Lall and Kraemer, 2005 [4]). Despite comparatively poor economic conditions of SSA countries (UNIDO, 2008 [5]), studies on the world's FDI inflow show that there has been a considerable increase in FDI flows worldwide as the figure US5 billion dollars (1995) rising to US18 billion (2005) is a vivid indication. As SSA's share of the world's FDI stocks is disappointingly pegged at $1 \%$ (UNIDO, 2008 [5]). It is still a fundamental obligation of policy makers across the African region to develop measures to attract FDI into their respective domestic economies, due to recent global attention to the needs and impacts of FDI on emerging economies. Empirical literature noted that a nation's ability to attract a maximum FDI flow strongly depends on its own peculiar factor characteristics (Lipsey, 2001 [6]; Demirhan \& Masca, 2008 [7]). Çevis and Çamurdan (2007) [8] noted that factors such as inflation rate, the interest rate, the growth rate, and the trade (openness) rate drive FDI flows as they contended that FDI inflows give power to the economies of host countries. Natural resources, GDP growth (measures market size) and many more are factors that researchers highly recognized as having impact on the determination of FDI flow (Jadhav, 2012 [9]; Ezeoha and Cattaneo, 2011 [10]; Frenkel et al., 2004 [11]; and Bennett, 2005 [12]). The disparities in globalization have highly affected SSA (Chang, 2007 [13]) as trade agreements in its regional boundaries are illogical (Schiff and Wnters, 2003 [14]; Yang and Gupta, 2005 [15]). Asymmetries exist within the region (SSA) with most of 
the lesser inflows of FDI going to primary resource sectors (UNIDO, 2008 [5]), yet empirical studies on FDI in SSA prove to be limited (Bartels et al., 2002 [16]).

Many studies have been conducted to investigate FDI determinants across the world, but, interestingly, none has been done in landlocked countries of Africa. This paper seeks to investigate the impact of the possible determinants or factors that smoothly drive or impede the flow of FDI to landlocked countries in Sub-Saharan Africa. This study contributes to existing literature on FDI determinants for the first time by investigating the landlocked countries in Sub-Saharan Africa with similar economic and social characteristics with the inclusion of natural resource endowments of such countries, the tax policies, as well as the political constraints that the sample countries are characterized with.

The structures of the subsequent sections are as follows: Section 2 explores the theoretical and empirical literature on determinants of FDI, Section 3 explains the data set on landlocked countries in Sub-Saharan Africa ${ }^{1}$ used for this study. Sections 4 and 5 discuss the results of the empirical analysis, findings and conclusions, respectively.

\section{Literature Review}

Despite few doubts on the capabilities of FDI as its impacts on the recipient economies are not clearly established (Alfaro et al., 2006 [17]; Borensztein \& Gregorio et al., 1995 [18]), different theoretical literature exists to create public awareness of its (FDI) needs as one of the major forces behind globalization (Cotton \& Ramachandran, 2001 [19]). There are many theories that doubly serve as significant steps toward the development of a systematic framework for emergence and attempt to explain the determinants of FDI (Demirhan \& Masca, 2008 [7]).

However, the ability of each to serve as a 'one in all' theory to explain all kinds of FDI either at the outward or inward FDI at country level (Demirhan \& Masca, 2008 [7]) has been accordingly questioned by various scholars including the likes of (Agarwal, 1980 [20]; Parry, 1985 [21]; Itaki, 1991 [22]). Even though an individual country can have an equally considerable number of motivations to undertake FDI (Jadhav, 2012 [9]). Contributing to the discussion of different theories that exist to better explain the kinds and determinants of FDI, however (Smith, 1976 [23]), as cited in (Skousen, 2007 [24]), criticized the economic philosophy of the mercantilists that encourage exports and discourage imports to get more gold and silver, yet it was with the view that the two engines by which the mercantilists enrich every country are the encouragement of exportation and discouragement of importation. By comparing the differences that exist between FDI and Portfolio Investment, theories of FDI were clearly explained and based on the portfolio investment theory, capital movements from locations where there are low interest rates to where there are high interest rates until interest rates are equalized everywhere (Hymer, 1976 [25]).

Regardless of the significant role FDI plays in the development of emerging economies (Musonera, 2008 [26]) and extensive classification of FDI inflow's determinants by the UNCTAD 1998 report [27], there are some controversies in the literature because existing empirical studies have accordingly considered different combinations of these determinants with mixed results, not only with their statistical significance but in terms of the direction of their effect on FDI inflows (Demirhan \& Masca, 2008 [7]). This suggests that there are many determinants and their relations to FDI cited in the empirical studies.

Mehic et al. (2013) [28] assessed that the level of FDI impact on growth depends on the magnitude at which it (FDI) is being complemented or substituted with the host countries' domestic investment. This assertion clearly signifies that the quantity of FDI inflows will determined by the existing domestic investment, as the country with less domestic investment is likely to receive more FDI to increase

1 The sample countries are Botswana, Burkina Faso, Burundi, Central African Republic, Chad, Ethiopia, Lesotho, Malawi, Mali, Rwanda, Swaziland, Uganda, and Zambia. Zimbabwe was excluded from the sample because of data availability. 
the stock of capital for developmental growth. This notion was to some extent in consistent with Ndikumana and Verick (2007) [29] who found out, using a fixed-effect estimator, that FDI is higher in countries where both private and public investment ratios are higher with a strong correlation between FDI and private investment.

In spite of substantial literature agitating for availability of high-quality but cheap labor force, the issues regarding human capital across global frontiers especially in Africa still remain arguable. While some researchers maintain that availability of relatively skilled labor does not have any greater impact on the location of Multinational Corporations (MNCs, Morisset, 2000 [30]). Others, including the likes of (Lemi and Asefa, 2003 [31]; Asiedu, 2006 [32]), believe that an educated labor force plays a crucial role in attracting FDI flows to host countries especially in Africa. Nevertheless, Noorbakhsh et al. (2001) [33] examined the relationship between human capital and FDI inflows in developing countries using different proxies of human capital. Including variables such as secondary school enrollment, accumulated years of secondary schooling, as well as combined tertiary and secondary education in a working population, they find all three independent variables to be significant in a panel analysis using white correction methodology with fixed-effect region specific dummies. In addition, Abbas and El Mosallamy (2016) [34] investigated the relationship between FDI and human capital in the Middle East and North Africa (MENA) for the period between 2006 and 2013. The findings suggested that human capital plays a role in attracting FDI to the region.

How open a country is to the external market participants to has impact to some extent on its ability to attract FDI. However, there exists mixed evidence concerning the significance of openness measured mostly by the ratio of exports plus imports to GDP in determining FDI (Charkrabarti, 2001 [35]). Quite a number of studies like (Kravis and Lipsey, 1982 [36]; Culem, 1988 [37], and Edwards, 1990 [38], Asiedu (2006) [32], Abbas and El Mosallamy (2016) [34] found a strong positive effect of openness on FDI flows. Schmitz and Bieeri (1972) [39] found a weak and significant link between the two variables. The most recent view on the openness-FDI effect probably comes from Jordaan (2004) [40] who asserted that the impact of openness on FDI strongly depends on the type of investment and further contended that when investments are market-seeking, trade restrictions, and, for that matter, less openness, can have a positive impact on FDI because the foreign firms that are being restricted from importing into host countries can decide to set up subsidiaries in the host countries. In addition, Pärletun (2008) [41] finds a positive relationship between trade openness and FDI to be statistically significant. Using panel unit-root test and multiple regressions with panel data for a period of ten years (2000-2009), Jadhav (2012) [9] finds that trade openness is positive, which implies that this variable has a positive effect on total inward FDI in Brazil, Russia, India, China and the South African (BRICS) economies. Investigating the determinants of FDI flows in the Central and Eastern European countries through the incorporation of the traditional factors and institutional variables over the period 1996-2009 using a disaggregated sectorial FDI dataset, Tintin (2011) estimated results verifying the economically significant effect of openness on FDI flows in Central and Eastern European countries. The study further contended that the determinant (openness) differs across three sectors, namely primary, manufacturing and services.

The responsiveness of FDI flow to foreign exchange rates has been examined both with respect to the changes in the bilateral levels of exchange rates between countries and in the volatility of the exchange rate (Blonigen, 2005 [42]). Froot and Jeremy (1991) [43] provided empirical evidence of increased inward FDI with depreciation through simple regressions using a small number of annual US aggregate observations of FDI flows, which Blonigen (2008) [44] applauded to have eradicated the common wisdom that changes in the level of the exchange rate would not change the decision by a firm to invest in a foreign country. Blonigen (1997) [45] used industry-level data on Japanese mergers and acquisition FDI into the US to provide another way in which changes in the exchange rate level may affect inward FDI for a host country. He found the strong support of an increased inward US acquisition by Japanese firms in response to the dollar depreciations relative to their local currency (yen). Lipsey (2001) [6] studied US FDI in three main regions during the period of their respective 
currency crisis (Latin America in 1982, Mexico in 1994, and East Asia in 1997) and found out that the inflows of FDI are more stable than other flows of capital during such specified period of crisis.

Any meaningful investment either undertaken domestically or across national borders requires a thorough insight into the inherent political constrains (in the form of government regulations, ordinary citizens' political rights and rampant changes in government peculiar to Sub-Saharan Africa), or awareness of the general environment of the destination country by investors (Filipe et al., 2012 [46]). As far as investment is concerned, managing an inherent constraint or risk is seen as a key factor that determines companies' decisions about international investment (Filipe et al., 2012 [46]).

Busse and Hsfeker (2005) [47] studied the relationship between political risk, institutions and FDI flows using different econometric techniques for 83 developing countries' data samples for the period 1984-2003. Their study revealed that an absence of internal conflict as well as ethnic tension, government stability, basic democratic rights and order significantly determine an inflow of FDI. Benáček et al. (2012) [48] considered political risk and institutions as important drivers of FDI for 32 European countries using panel regression techniques in two specifications over the period 1995-2008. The study revealed that two variables considered in both static and dynamic perspectives significantly influence investors' behavior. Harms and Ursprung (2002) [49] used Raymond Gastil indices (which rank countries' political rights on a scale of one to seven, one signifying greater political freedom) to examine whether countries with civil and political repressed receive attention from multinational corporations and attract low or high FDI. Using the OLS technique, they found a negative and significant relationship between the dependent variable (FDI Flow) and all the indices (civil and political repressed) used, which clearly depicts that countries with political rights receive greater inflow of FDI. This finding was not different from that of Bennett (2005) [12] who investigated the propensity of political and other variables to determine the pattern of FDI growth in Africa using panel data from 22 Sub-Saharan African nations over the period 1982-2000. The study points out that the degree of political right statistically and significantly explains the quantity of FDI inflows into the host countries. Abbas and El Mosallamy (2016) [34] investigated the relationship between FDI and political stability in the MENA region for the period spans from 2006 to 2013. The findings suggested that political stability is not a determinant for FDI to the region during the tested period.

Considering the interest in the effects of taxes on FDI, as it has been considerable from both international and public economists (Blonigen, 2005 [42]), the effects of taxes vary substantially by types, measurement of FDI activities, as well as their treatment in both host and parent countries. Most of the existing literature on Tax Policy-FDI effects points to Hartman's paper (1984 [50]; 1985 [51]) as it first spelled out a way in which certain types of FDI such as transferred FDI may not be sensitive to taxes.

An attempt to address the problem of double taxation emerged from Hartman's study when the transferred FDI is subjected to tax in both parent (foreign) and host countries. Estimating a cross-sectional econometric model to determine factors of FDI flows in developing countries over the period of 2000-2004 with a sample of 38 developing countries, Demirhan and Masca (2008) [7] found a negative and statistically significant relation between FDI flow and tax rate. Bellak and Leibrecht (2005) [52] estimated a panel of 56 bilateral country-relationships of seven home and eight host countries (central and East European) of FDI from 1995-2003 with the use of a panel gravity-model setting to analyze the role of taxation as determinants of FDI. Their study revealed that a one percent point increase in the effective tax rate on FDI decreases FDI flows by about 4.4 percent, all things being equal. The empirical literature still remains literally indecisive with respect to whether FDI would accordingly respond to tax policies. Some studies have revealed that host countries' corporate tax policies have negative and significant effects on FDI flows, while others strongly believe that taxes do not have any significant effect on FDI flow. Researchers such as Grubert and Mutti (1991) [53], Hines and Rice (1994) [54], Cassou (1997) [55] and Kemsley (1998) [56] found in their respective studies that host countries' corporate income taxes have a negative and significant effect on attracting FDI. 
Root and Ahmed (1979) [57], Lim (1983) [58] and Yulin and Reed (1995) [59] also found a positive relationship between the two variables (FDI and tax).

Frenkel et al. (2004) [11] assessed the factors that influence FDI inflow concentrating on bilateral FDI flow between five home countries and 22 emerging economies in Asia, Latin America, Central and Eastern Europe GDP growth, which measures their respective market sizes. Via employing panel data analysis based on gravity, the study finds that GDP growth rate is important and has a significant role for FDI inflow. Çevis \& Çamurdan (2007) [8] estimated the economic determinants of FDI flows for the period 1989:01-2006:04 using a panel data set of 17 developing countries and transition economies with GDP growth (measuring market size) and other variables as independent variables. Their results revealed that FDI flow is positively related with GDP growth rate. Using panel data from 22 Sub-Saharan Africa nations, Bennett (2005) [12] used three different regression procedures, GDP and other variables as indicators to explain FDI inflows over the period 1982-2000. Bennett's findings suggest that GDP which measures market size is positive and statistically significant in all models employed in the study. Evoking econometric studies on 29 SSA countries over the period 1990-1997, Morisset (2000) [30] found GDP (measuring market size) as having a positive impact on FDI flows using panel data with an elasticity of 0.92 and 1.2 using cross-sectional data. Liargovas and Skandalis (2012) [60] examined the link between FDI and GDP growth and other indicators of 36 developing countries all over the world (12 Latin American, 10 Asian, four African and four commonwealth of independent states and six Eastern European countries) for their study over the period 1990-2008. Employing a fixed effect model to analyze data, their results revealed market size using GDP as a proxy as a factor positively affecting FDI inflow. Asiedu (2006) [32] analyzed the impact of real GDP growth on selected countries in Africa and Asia. They found that FDI inflow is positively related to GDP growth as a proxy of market size in both regions.

The common perception in the SSA and across the world is that FDI is largely driven by natural resources (Asiedu, 2006 [32]). This commonly embraced perception is consistent with data from the World Bank, which revealed the three largest recipients of FDI in SSA to be South Africa, Nigeria and Angola (absorbing about 65\%-thus, 36\%, 16\% and 13\%, respectively, of FDI inflows to the region) over the period 2000-2002 with their natural resources endowments as proxy (World Bank, 2004 [61]). Jadhav (2012) [9] examined the significant determinants of FDI in Brazil, Russia, India, China and South Africa (BRICS) economy using panel unit-root test and multiple regressions with panel data for a period of ten years (2000-2009). Jadhav indicated a statistically significant and negative effect of natural resources availability on total inward FDI; this explains that FDI is not motivated by resource-seeking purposes in such economies. Using fixed-effects panel estimation and an unbalanced panel data for 22 countries over the period 1984-2000, Asiedu (2006) [32] found out that natural resources have significant and positive impact on FDI inflows in Africa. Ezeoha and Cattaneo (2011) [10] used panel data spanning 1995-2008 with data from 30 SSA countries to analyze the role natural resources play in attracting FDI into such regions. Their study revealed a significantly positive impact of natural resource endowment on FDI attraction, which justifies why countries significantly endowed with natural resources like crude oil, gold and diamonds historically account for the bulk of FDI flows. This is inconsistent with Asiedu (2003) [62] who utilizes the diverse theory that all else equal countries rich in natural resources should receive more FDI than less endowed countries. Using panel data from 22 SSA countries and employing three separate regression processes with the first one ignoring country heterogeneity, the second utilizes regional dummies to correct for country fixed effect and the last uses country dummies in order to explain FDI flows over the period 1982-2000, and Bennett (2005) [12] finds that crude oil production are statistically important in explaining FDI inflows to the countries.

\section{Financial Reforms in SSA}

Magnification of a coherent growth in the Sub-Saharan African economy is vitally reliant on further endorsements in the financial development of its markets. Such magnification demands more extensive implementation of the markets financial tradable assets, adequate use of capital and 
tightening any possibility of agency risk, and managers to benefit from their positions for their own sake (Chami, Fullenkamp and Sharma, 2010 [63]).

Agency risk deteriorates substantially under extrinsic demand and foreign financing circumstances. A common ground is reached among scholars on both sides of the literature, theoretical and empirical, that enhancement of financial development influences higher economic growth, despite the debate over whether it pushes for financial development around the country and growth or is simply a lubricant. Engine factor can significantly improve the prospects for economic growth, which is worth studying in detail. Most countries of Sub-Saharan Africa in the most recent four decades have achieved higher financial development standards with the exclusion of middle-income countries from this financial advancement. Innovation and utilization of technology on financial instruments expanded access to the population and raised their financial integration among different countries particularly low-income and fragile countries.

Financial depth levels in Sub-Saharan Africa has not yet caught up with other development regions although credit to GDP percent average of Sub-Saharan Africa amid the period of 1995 to 2014 has increased from a 10 percent average to a 21 percent average point. For example, banking sector depth in Sub-Saharan Africa is about half the size of other development regions resting at an average of 57 percent to GDP. Therefore, empirical estimates suggest financial development decreases volatility in Sub-Saharan Africa.

Practitioners and empirical reviewers witnessed improvements in economic growth policies reaching more stable economies after improvements in financial development in certain countries. No doubt better mobilization of financial resources laid its shade on such economies and helped improve them. Regardless of what practitioners in real life experienced, some academic literature still claims that financial development negatively influences economic growth and its volatility (Sahay et al., 2015 [64]).

\section{Econometric Methodology and Data}

In order to investigate the determinants of Foreign Direct Investment (FDI) for the "landlocked countries" in Sub-Saharan Africa, the present research is conducted using panel data analysis, which is seen as a powerful research technique that can be used to measure the effect of any variables of interest over a period of time (time-series) and across country (cross-sectional panel) data methodology is used to reduce the time-varying and multicollinearity between endogenous and exogenous variables. After verifying the Heterogeneity of panel time series as follows:

$$
Y_{i t}=\varphi_{i}+x^{\prime}{ }_{i t} \beta_{i}+\varepsilon_{i t}, i=1, \ldots, N,
$$

where it was assumed that $\varepsilon_{i t} \sim \operatorname{IID}\left(0, \sigma_{\varepsilon, i}^{2}\right)$. Pooling the data or not depends on whether the data could be imposed on the homogeneity of slope coefficients-if $\beta_{i}=\beta$ and $\sigma_{\varepsilon, i}^{2}=\sigma_{\varepsilon}^{2}$ for all $i$, upon assuming $\varepsilon_{i t}$ and $\varphi_{i}$ are independent across units. Therefore, the model reduces to the fixed or random effects model. In order to determine the model specification, the fixed effects model should outperform the pooled OLS by using the F-test and Pagan Lagrange Multiplier (LM) test to determine the random effect model outperforming the pooled OLS. The Hausman test is used to contrast the random effects model compared with the fixed effects model. For diagnostic purposes, Baltagi LM test for autocorrelation and an Erlat LM test for heteroskedasticity were applied.

The data set of this research consisted of observations made from a sample of 13 countries (number of countries $i$ ) out of 14 countries due to data availability over the period of 1995 to 2013, ( $t$ time period) in landlocked countries, expressed as follows:

$$
\begin{aligned}
& o g F D I_{i t}=\beta_{0}+\beta_{1} D I g_{i t}+\beta_{2} H C_{i t}+\beta_{3} \log (O P E N g)_{i t}+\beta_{40 t P g t h)(c o u n t r i e s) I)} E X R_{i t}+ \\
& \beta_{5} P C_{i t}+\beta_{60 t P g \text { th })(0 u n t r i e s) I)} T A X g_{i t}+\beta_{7} M Z_{i t}+\beta_{80 t P g t h)(o u n t r i e s) I)} N R E_{i t}+\varepsilon_{i t} \text {, }
\end{aligned}
$$


where FDI represents the foreign direct investment, Dig denotes the Domestic investment percent of GDP, HC denotes the Human Capital (secondary school enrollment as a proxy), OPENg denotes the openness of trade percent of GDP, EXR denotes the exchange rate, $P C$ denotes the political constraints index (as a proxy of the feasibility of policy changes), TAXg denotes the corporate tax percent of GDP, $M Z$ denotes the market size (as a proxy of GDP growth), and NRE denotes the natural resources endowment. $\varepsilon_{i t}$ is the random error. Determining the appropriate model fixed effects or random effects model depends on the structure of the random error.

\section{Econometric Results}

In the diagnostic results of autocorrelation and heteroskedasticity as shown in Table 1, we fail to reject that the null hypothesis of the variance of the error term is constant $H_{0}: V\left(\varepsilon_{j}\right)=\sigma^{2}=0$, which means that the model is homoscedastic in terms of heteroskedasticity). However, according to the LM test, as reported in Table 1, we fail to reject the null hypothesis of equal variances $\left(H_{0}: \sigma_{\mu}^{2}=\sigma_{\lambda}^{2}=0\right)$, which means that there is an autocorrelation problem in the model. In order to remedy the autocorrelation problem by using the Chchrane-Orcutt; Generalized Least Squares (GLS) method, the model were estimated as follows:

$$
\varepsilon_{i t}=\rho_{1} \varepsilon_{i, t-1}+\psi_{i t,} i=1, \ldots, N,
$$

where $\rho_{1}(R H O),-1<\rho<1$, and it was assumed that $\psi_{i t} \sim \operatorname{IID}\left(0, \sigma_{\psi, i}^{2}\right)$ were white noise residuals. Hence, the model was transformed by substituting the estimated value of $\hat{\rho}$ in Equation (2) as shown below:

$$
\left(Y_{i t}-\hat{\rho} Y_{i, t-1}\right)=\beta_{0}(1-\hat{\rho})+\sum_{i=1}^{n=8} \beta_{i}\left(X_{i t}-\hat{\rho} X_{i, t-1}\right)+\left(\varepsilon_{i t}-\hat{\rho} \varepsilon_{i, t-1}\right),
$$

where $\hat{\rho}$ denotes the coefficient of autocovariance, $Y_{i, t-1}, X_{i, t-1}$ represents the lag of the dependent and independent variables, respectively, and $\varepsilon_{i t}$ is the random error. As shown in Table 2, the results indicate that the fixed and random effects models, which outperformed the pooled OLS, depended on the F-test and BP-test. As reported in Table 2, the Hausman test indicates that random effects is the appropriate model. In addition, the diagnostic test results, the Baltagi LM test and the Erlat LM test indicate that there are no autocorrelation and heteroskedasticity problems in the GLS model.

Table 1. The results of the autocorrelation and heteroskedasticity test.

\begin{tabular}{ccc}
\hline Autocorrelation Test & \multicolumn{2}{c}{ Heteroskedasticity Test } \\
\hline LMrho_chi-sqr(1) $=9.74244$ & LMh-OLS & LMh-fixed \\
$p$-Value $=0.00180$ & chi-sqr(12) $=32.6617$ & chi-sqr $(12)=35.1948$ \\
Durbin-Watson $=1.3830$ & $p$-Value $=0.3501$ & $p$-Value $=0.10210$ \\
\hline
\end{tabular}

Table 2. The coefficient estimation from regressing log (FDI) determinants, years 1995-2013.

\begin{tabular}{ccc}
\hline \multirow{2}{*}{ Independent Variables } & \multicolumn{2}{c}{ Foreign Direct Investment (FDI) } \\
\cline { 2 - 3 } & Pooled OLS & Random Effects \\
\hline \multirow{2}{*}{ Constant } & 12.0831 & 13.0013 \\
& $(0.2770)^{* *}$ & $(0.584024)^{* * *}$ \\
\hline \multirow{2}{*}{$D I g_{i t}$} & 0.0399 & 0.04501 \\
& $(0.0044)^{* * *}$ & $(0.01555)^{* * *}$ \\
\hline \multirow{2}{*}{$H C_{i t}$} & 0.04099 & 0.04513 \\
& $(0.00302)^{* * *}$ & $(0.010488)^{* * *}$ \\
\hline
\end{tabular}


Table 2. Cont.

\begin{tabular}{|c|c|c|}
\hline \multirow{2}{*}{ Independent Variables } & \multicolumn{2}{|c|}{ Foreign Direct Investment (FDI) } \\
\hline & Pooled OLS & Random Effects \\
\hline $\log (O P E N g)_{i t}$ & $\begin{array}{c}1.0725 \\
(0.10183)^{* * *}\end{array}$ & $\begin{array}{c}1.10085 \\
(0.374066)^{* * *}\end{array}$ \\
\hline$E X R_{i t}$ & $\begin{array}{c}-0.00025 \\
(0.0002)\end{array}$ & $\begin{array}{c}0.00017 \\
(0.000737)\end{array}$ \\
\hline$P C_{i t}$ & $\begin{array}{c}1.0898 \\
(0.15355) * * *\end{array}$ & $\begin{array}{c}1.1637 \\
(0.561380) * *\end{array}$ \\
\hline $\mathrm{T} A \mathrm{Xg}_{\text {it }}$ & $\begin{array}{c}-2.0324 \\
(0.33178)\end{array}$ & $\begin{array}{c}-2.1082 \\
(1.219672)\end{array}$ \\
\hline$M Z_{i t}$ & $\begin{array}{c}0.0352 \\
(0.00514)^{* * *}\end{array}$ & $\begin{array}{c}0.035976 \\
(0.018913) *\end{array}$ \\
\hline$N R E_{i t}$ & $\begin{array}{c}0.03407 \\
(0.03407)^{* * *}\end{array}$ & $\begin{array}{c}0.038184 \\
(0.018821)^{* *}\end{array}$ \\
\hline$N$ & 221 & 221 \\
\hline$R$-squared & 0.68 & 0.68 \\
\hline Adjusted $R$-squared & 0.66 & 0.65 \\
\hline$F$-statistic & $33.229 * * *$ & $21.632 * * *$ \\
\hline \multicolumn{3}{|c|}{ Specification tests } \\
\hline \multirow{5}{*}{\multicolumn{2}{|c|}{$\begin{array}{l}\text { F-test (pooled OLS vs. FEM) } \\
\text { PB-test (pooled OLS vs. REM) } \\
\text { Hausman test Random Effect } \\
\text { Autocorrelation: Baltagi LM test } \\
\text { Heteroskedasticity: Erlat LM test }\end{array}$}} & $41.99^{* * *}$ \\
\hline & & $14.12 * * *$ \\
\hline & & 0.3513 \\
\hline & & $x^{2}: 0.0075$ \\
\hline & & $x^{2}: 35.19$ \\
\hline
\end{tabular}

$*$ ** and *** denote significant level at $10 \%, 5 \%$ and $1 \%$ respectively; based on Standard errors are in parentheses; note: the null hypotheses of residuals tests are that the residuals do not display any serial correlation and are homoscedastic.

\section{Discussion of the Empirical Results}

As portrayed in Table 2 above, the empirical results revealed a positive relationship between domestic investments and FDI flows into the host country's economy. This positive relationship signifies a complement between the two variables. As FDI has no crowding out effect on domestic investment, its (FDI) flow comes to increase the stock of capital raised through domestic investment. This finding is consistent with Ndikumana and Verick (2007) [29] who found FDI flow to be higher in countries where both private and public investment ratios are higher with correlation between FDI. It also signifies the level of confidence that domestic investors have in their countries, which is serving as proxy for the foreign investors to invest in such countries, and an increase in the domestic investment denotes efficiencies in the economies of the sample countries.

With human capital as per the revealed empirical results of the study, the positive and significant relationships shown between human capital and FDI confirms an assertion that educated labour force plays a crucial role in attracting FDI flows to host countries (Lemi and Asefa, 2003 [31]; Asiedu, 2006 [32]). This suggests that, as the level of literacy rate among the labour force increases, the flow of FDI retrospectively increases. In addition, the existence of knowledgeable and skilled personnel among the labor force raises investors' confidence that their investments would be effectively managed.

The relationship between FDI and the trade openness is seen to be positive and significant in the sample countries. Our finding is consistent with Jadhav (2012) [9] who found positive trade openness to imply a positive effect on total inward FDI in Brazil, Russia, India, China and South African (BRICS) economies. This level of openness suggests that the types of investments to such countries are market and resource-seekers, and, for that matter, the existence of trade restrictions (very keen in SSA) and 
even strict tax policies meant to limit the movements of capital from either neighboring or western countries rather than encourage the foreigners to set up their subsidiaries in the host countries as strongly contended by Jordaan (2004) [40]. This positive relationship could also be ascribed to an effort of the African Union (AU) to promote trade alliances among its member countries by lessening the burdens these countries suffer in the form of high costs when their imports and exports have to transit through other neighboring countries before getting to their required destinations.

Like Harms and Ursprung (2002) [49] and Bennett (2005) [12], our result revealed a positive and significant relationship between political constraint (measured using countries' political rights and freedom, democracy and changes in governance) and the FDI flow. This suggests the ease at which government executives can change policies in the sampled countries, and, as investors pay key attention to the inherent political constraints in the host country before considering any investment decision, countries with political freedom and understanding of democracy tend to receive attention from multinational corporations and attract high FDI. This does not mean an absolute ascription of political freedom and democracy in Africa Sub regions, but a gradual observance of democracy and political freedom to citizens has gained global recognition. Moreover, the level of stability in governance and desist from regional and tribal discriminations assure investors safety, and, for that matter, attract high FDI flow into such countries.

A negative and significant relationship revealed between the host countries' tax and their lagged FDI, which is in agreement with Demirhan and Masca (2008) [7], clearly signifies that changes in tax policies and regulations of 'landlocked countries' in the past indeed affected the quantity of FDI received within such a period. This result suggests that the tax policies in the host country affect the retained earnings FDI as they respond significantly to the tax rates of the host country more than the transferred earning FDI. This could be due to the fact that, despite these countries being, to some extent, endowed with huge reserves of natural resources, they still resort to high taxes as a major source of revenue to the countries.

Consistent with Liargovas and Skandalis (2012) [60], our study empirically revealed a positive and significant relationship between market size (GDP as a proxy) and FDI. This result is clearly justified by an assertion that investors have an intention of accruing maximum returns on their investments. Since the market size is determined by the economic standards, imports and exports of the related countries, nations experiencing an improvement in any of these are able to attract maximum FDI into their economy. Though not highly significant, the result shows that little improvement in the sampled countries' past GDP had significant impact on their lagged FDI.

Finally, looking at the sample countries' peculiar characteristics, a positive and significant relationship was revealed between natural resources that the sample countries are endowed with and the FDI. Most of our sampled countries are indeed endowed with natural resources. This justifies the common perception that FDI is largely driven by natural resources, as Asiedu (2006) [32] asserted, and is also in agreement with Ezeoha and Cattaneo (2011) [10] that natural resources have significant and positive impact on FDI inflow in Africa and also justifies why countries significantly endowed with natural resources historically account for the bulk of FDI flow compared to less endowed countries.

\section{Conclusions}

In summary, certain factors play a crucial role in attracting FDI into host countries' economies. Therefore, policy makers ought to pay much attention to creating an attractive atmosphere to encourage investment (UNIDO, 2008 [5]). As envisaged from the results, variables such as trade (openness), natural resources endowment, domestic investment, human capital, political constraint as well as market size have positive and significant impact on FDI flow. Countries are therefore endeavoring to implement strategies that will accordingly improve their ability to attract maximum FDI flow as it is understood that the previous FDI is directly related to the host country's specific characteristics. As Henisz (2002) [65] noted, political environments that limit the feasibility of policy change are important determinants of investment in infrastructure, and the result of our study revealed that 
as the government executives attained the ease to change policies lagged, FDI inflow increased and vice versa. Therefore, measures such as public education to create awareness of the need to desist from ethnic conflicts and regional discriminations that the 'landlocked' countries in SSA are said to prone to should be embarked upon. This measure is highly seen to have the capacity to strategically position the countries' democracies, which, in turn, enhance their ability to attract maximum FDI into their respective economies. Finally, our study revealed an inverse correlation between tax policies of these countries and FDI, which denotes that as the host countries amend their tax policies to charge higher taxes on the returns accrued on investments, investors recoiled into their shells, an attitude which eventually causes a reduction in total FDI. As an antidote to these investors' reserved attitudes, the policy makers in such countries should alleviate the tax burdens on the investors, though they should not necessarily grant them a thorough 'tax holiday' since that strategy will also have a negative impact on government revenue from taxation.

Author Contributions: All authors contributed equally to the paper.

Conflicts of Interest: The authors declare no conflict of interest.

\section{References}

1. Fosu, A.W.; Krishman, P.; Ndikumana, L. Africa and the World Economy: A Focus on Capital-An Overview. J. Afr. Econ. 2004, 13, ii1-ii14. [CrossRef]

2. Arrighi, G. The African Crisis. New Left Rev. 2002, 15, 5-36.

3. Ayittey, G.B.N. Africa Unchained; Palgrave MacMillan: London, UK, 2005.

4. Lall, S.; Kraemer-Mbula, E. Is African Industry Competing? QEH Working Paper Series, Working Paper No. 121; University of Oxford: Oxford, UK, 2005.

5. United Nations Industrial Development Organization. Foreign Direct Investment in Sub-Saharan Africa: Determinants and Location Decisions; Research and Statistics Branch; Working Paper 08/2008; UNIDO: Vienna, Austria, 2008.

6. Lipsey, R.E. Foreign Direct Investment and the Operations of Multinational Firms: Concepts, History, and Data; National Bureau of Economic Research: Cambridge, MA, USA, 2011.

7. Demirhan, E.; Masca, M. Determinants of Foreign Direct Investment Flows; Prague Economic Papers; University of Economics: Prague, Czech Republic, 2008.

8. Çevis, I.; Çamurdan, B. The Economic Determinants of Foreign Direct Investment in Developing Countries and Transition Economies, the Pak. Dev. Rev. 2007, 46, 285-299.

9. Jadhav, P. Determinants of foreign direct investment in BRICS economies: Analysis of economic, institutional and political factor. Procedia Soc. Behav. Sci. 2012, 37, 5-14. [CrossRef]

10. Ezeoha, A.E.; Cattaneo, N. FDI Flows to Sub-Saharan Africa: The Impact of Finance, Institution and Natural Resource Endowment. Comp. Econ. Stud. 2012, 54, 597-632. [CrossRef]

11. Frenkel, M.; Funke, K.; Stadtmann, G. A panel analysis of bilateral flows to emerging economies. Econ Syst. 2004, 28, 281-300. [CrossRef]

12. Bennett, R. Theory and Evidence: The Determinants of FDI in Sub-Saharan Africa. Bachelor's Thesis, Leonard N. Stern School of Business, New York University, New York, NY, USA, 2005.

13. Chang, H. Incentives, Capabilities, and Space-The Evolution of World Trading System and the Future of Developing Countries. In Presented at the UNCTAD Meeting of Experts on FDI, Technology and Competitiveness, Geneva, Switzerland, 8-9 March 2007.

14. Schiff, M.; Winters, L.A. Regional Integration and Development; World Bank: Washington, DC, USA; Oxford University Press: Oxford, UK, 2003.

15. Yang, Y.; Gupta, S. Regional Trade Arrangements in Africa: Past Performance and the Way Forward; International Monetary Fund WP/05/36; International Monetary Fund: Washington, DC, USA, 2005.

16. Bartels, F.L.; Johnson, J.P.; Ahmed, Z.U. International Equity Joint Ventures in Ghana and Côte D'Ivoire: The Experience of British and French Firms. J. Afr. Bus. 2003, 3, 5-30. [CrossRef]

17. Alfaro, L.; Chanda, A.; Kalemli-Ozcan, S.; Sayek, S. How Does Foreign Direct Investment Promote Economic Growth? Exploring the Effects of Financial Markets on Linkages; National Bureau of Economic Research: Cambridge, MA, USA, 2006. 
18. Borensztein, E.; De Gregorio, J.; Lee, J.W. How Does Foreign Direct Investment Affect Economic Growth? Working Paper Series No. 5057; National Bureau of Economic Research: Cambridge, MA, USA, 1995.

19. Cotton, L.; Ramachandran, V. Foreign Direct Investment in Emerging Economies Lessons from Sub-Saharan Africa; Discussion Paper No. 2001/82; World Institute for Development Economics Research: Helsinki, Finland, 2001.

20. Agarwal, J.P. Determinants of Foreign Direct Investment: A Survey. Weltwirtschaftliches Arch. 1980, 116, 739-773. [CrossRef]

21. Parry, T.G. Internalization as a General Theory of Foreign Investment: A Critique. Weltwirtschaftliches Arch. 1985, 121, 564-569. [CrossRef]

22. Itaki, M. A Critical Assessment of the Eclectic Theory of the Multinational Enterprise. J. Int. Bus. Stud. 1991, 25, 445-460. [CrossRef]

23. Smith, A. An Inquiry into the Nature and Causes of the Wealth of Nations; University of Chicago: Chicago, IL, USA, 1976.

24. Skousen, M. The Structure of Production; NYU Press: New York, NY, USA, 2007.

25. Hymer, S.H. The International Operations of National Firms: A Study of Direct Foreign Investment; MIT Press: Cambridge, MA, USA, 1976.

26. Musonera, E. Country Risk Factors: An Empirical Study of FDI Determinants in SSA. J. Int. Mang. Stud. 2008, 3, 1-9.

27. United Nations Conference on Trade and Development. World Investment Report (WIR) 1998: Trends and Determinants; UNCTAD: New York, NY, USA; Geneva, Switzerland, 1999.

28. Mehic, E.; Silajdzic, S.; Babic-Hodovic, V. The Impact of FDI on Economic Growth: Some Evidence from Southeast Europe. Emerg. Mark. Financ. Trade 2013, 49, 5-20. [CrossRef]

29. Ndikumana, L.; Verick, S. The Linkages between FDI and Domestic Investment: Unraveling the Developmental Impact of Foreign Investment; Economics Department Working Paper Series, Paper 25; OECD: Paris, France, 2007.

30. Morriset, J. Foreign Direct Investment in Africa: Policies Also Matter, Translational Corporations. Available online: http:/ /www.oecd.org/daf/inv/investmentstatisticsandanalysis/2408225.pdf (19 February 2016).

31. Lemi, A.; Asefa, S. Foreign Direct Investment and Uncertainty: Empirical Evidence from Africa. Afr. Financ. J. 2005, 5, 36-67.

32. Asiedu, E. Foreign Direct Investment in Africa: The Role of Natural Resources, Market Size, Government Policy, Institutions and Political Instability. World Econ. 2006, 29, 63-77. [CrossRef]

33. Noorbakhsh, F.; Paloni, A.; Youssef, A. Human Capital and FDI Inflows to Developing Countries: New Empirical Evidence. World Dev. 2001, 29, 1593-1610. [CrossRef]

34. Abbas, S.; El Mosallamy, D. Determinants of FDI Flows to Developing Countries: An Empirical Study on the MENA Region. J. Financ. Econ. 2016, 4, 30-38.

35. Charkrabarti, A. The Determinants of Foreign Direct Investment: Sensitivity Analyses of Cross-Country Regressions. Kyklos 2001, 54, 89-114. [CrossRef]

36. Kravis, I.B.; Lipsey, R.E. Location of Overseas Production and Production for Exports by U.S. Multinational Firms. J. Int. Econ. 1982, 12, 201-223. [CrossRef]

37. Culem, C.G. The Locational Determinants of Direct Investments among Industrialized Countries. Eur. Econ. Rev. 1998, 32, 885-904. [CrossRef]

38. Edwards, S. Capital Flows, Foreign Direct Investment, and Debt-Equity Swaps in Developing Countries; Working Paper No. 3497; NBER: Cambridge, MA, USA, 2008.

39. Schmitz, A.; Bieri, J. EEC Tariffs and US Direct Investment. Eur. Econ. Rev. 1972, 3, 259-270. [CrossRef]

40. Jordaan, J.C. Foreign Direct Investment and Neighboring Influences. Ph. D. Thesis, University of Pretoria, Pretoria, South Africa, 2006.

41. Pärletun, J. The Determinants of Foreign Direct Investment: A Regional Analysis with Focus on Belarus. 2008. Available online: http:/ / biblioteket.ehl.lu.se/olle/papers/0002948.pdf (accessed on 3 March 2015).

42. Blonigen, B.A. A Review of the Empirical Literature on FDI Determinants. Atl. Econ. J. 2005, 33, $383-403$. [CrossRef]

43. Froot, K.A.; Jeremy, C.S. Exchange Rates and Foreign Direct Investment: An Imperfect Capital Markets Approach. Q. J. Econ. 1991, 106, 1191-1217. [CrossRef] 
44. Blonigen, B. New Evidence on the Formation of Trade Policy Preferences; NBER Working Papers 14627; National Bureau of Economic Research, Inc.: Cambridge, MA, USA, 2008.

45. Blonigen, B.A. Firm-Specific Assets and the Link between Exchange Rates and Foreign Direct Investment. Am. Econ. Rev. 1997, 87, 447-465.

46. Filipe, J.; Ferreira, M.; Coelho, M.; Moura, D. FDI Political Risks: The New International Context. Int. J. Latest Trends Financ. Econ. Sci. 2012, 2, 117.

47. Busse, M.; Hefeker, C. Political Risk, Institutions and Foreign Direct Investment; Discussion Paper Series 26388; Hamburg Institute of International Economics: Hamburg, Germany, 2005.

48. Benáček, V.; Lenihan, H.; O'Callaghan, B.; Kan, D. Political Risk, Institutions and Foreign Direct Investment: How Do They Relate in Various European Countries? IES Working Paper: 24/2012; Charles University Prague: Prague, Czech Republic, 2012.

49. Harms, P.; Ursprung, H.W. Do Civil and Political Repression Really Boost Foreign Direct Investment? Econ. Inq. 2002, 40, 651-663. [CrossRef]

50. Hartman, D.G. Tax Policy and Foreign Direct Investment in the United States. Natl. Tax J. 1984, 37, 475-487.

51. Hartman, D.G. Tax Policy and Foreign Direct Investment. J. Public Econ. 1985, 26, 107-121. [CrossRef]

52. Bellak, C.; Leibrecht, M. Do Low Corporate Income Tax Rates Attract FDI? Evidence from Eight Central-and East European Countries; Research Paper 2005/43; The University of Nottingham: Nottingham, UK, 2005.

53. Grubert, H.; Mutti, J. Taxes, Tariffs and Transfer Pricing in Multinational Corporate Decision Making. Rev. Econ. Stat. 1991, 73, 285-293. [CrossRef]

54. Hines, J.R.; Rice, E.M. Fiscal Paradise: Foreign Tax Havens and American Business. Q. J. Econ. 1994, 109, 149-182. [CrossRef]

55. Cassou, S.P. The Link between Tax Rates and Foreign Direct Investment. Appl. Econ. 1997, 29, $1295-1301$. [CrossRef]

56. Kemsley, D. The Effect of Taxes on Production Location. J. Account. Res. 1998, 36, 321-341. [CrossRef]

57. Root, F.R.; Ahmed, A.A. Empirical Determinants of Manufacturing Direct Foreign Investment in Developing Countries. Econ. Dev. Cult. Chang. 1979, 27, 751-767. [CrossRef]

58. Lim, D. Fiscal Incentive and Direct Foreign Investment in Less Developed Countries. J. Dev. Stud. 1983, 19, 207-212. [CrossRef]

59. Yulin, N.; Reed, M.R. Locational Determinants of U.S. Direct Foreign Investment in Food and Kindered Products. Agrobusiness 1995, 11, 77-86.

60. Liargovas, P.G.; Skandalis, K.S. Foreign Direct Investment and Trade Openness: The Case of Developing Economies. Soc. Indic. Res. 2012, 106, 323-331. [CrossRef]

61. World Bank. Poverty Reduction Strategy Papers-Progress in Implementation; World Bank: Washington, DC, USA, 2004.

62. Asiedu, E. Foreign Direct Investment to Africa: The Role of Government Policy, Governance and Political Instability; University of Kansas: Mimeo, KS, USA, 2003.

63. Chami, R.; Fullenkamp, C.; Sharma, S. A framework for financial market development. J. Econ. Policy Reform 2010, 13, 107-135. [CrossRef]

64. Sahay, R.; Čihák, M.; N’Diaye, P.M.; Barajas, A.; Ayala Pena, D.B.; Bi, R.; Gao, Y.; Kyobe, A.J.; Nguyen, L.; Saborowski, C.; et al. Rethinking Financial Deepening: Stability and Growth in Emerging Markets; IMF Discussion Note, SDN/15/08; IMF: Washington, DC, USA, 2015.

65. Henisz, W. The Institutional Environment for Infrastructure Investment. Ind. Corp. Chang. 2002, 11, 355-389. [CrossRef]

(C) 2017 by the authors; licensee MDPI, Basel, Switzerland. This article is an open access article distributed under the terms and conditions of the Creative Commons Attribution (CC-BY) license (http://creativecommons.org/licenses/by/4.0/). 